\title{
Life satisfaction in Romanian cities on the road from post-communism transition to EU accession
}

\author{
Camilla Lenzi ${ }^{1}$ and Giovanni Perucca ${ }^{2}$ \\ ${ }^{1}$ Politecnico di Milano, Milano, Italy (email: camilla.lenzi@polimi.it) \\ 2 Politecnico di Milano, Milano, Italy (email: giovanni.perucca@polimi.it) \\ Received: 28 January 2016/Accepted: 25 May 2016
}

\begin{abstract}
The literature on life satisfaction in transition countries, and in particular on Romania, demonstrated that life satisfaction significantly differs across rural communities and cities of different sizes. The question addressed in this paper is whether these imbalances are stable over time, or instead, they become manifest in the presence of strong divergences in the economic growth rates of different kinds of communities. Results point out that in the period of sharp economic growth led by large urban areas, as the one experienced by Romania on the road to EU accession, rural/urban disparities in life satisfaction widened, favoring cities of intermediate size.
\end{abstract}

\section{Introduction}

The interest towards the determinants of life satisfaction largely increased in the last twenty years. An issue only partially explored by the literature, even if it is gaining momentum in recent years (Morrison 2014, Tomaney 2015, Piper 2015), concerns the relationship between urbanization and life satisfaction. This topic is particularly relevant in the case of transition and developing countries, characterized by huge divergences in the economic growth rates of urban and rural areas.

The relevance of geographic location for individual life satisfaction has been clearly demonstrated and persistent differences across space have been highlighted (Oswald, Wu 2010, Glaeser et al. 2016, Morrison 2011). Some works emphasized lower levels of happiness in cities compared to the countryside (Knight, Gunatilaka 2010, Hayo 2007, Sørensen 2014); others instead report no significant relationship between urbanization and well-being (Appleton, Song 2008, Rehdanz, Maddison 2005, Rodríguez-Pose, Maslauskaite 2012). Moreover, some authors indicate that the level of economic development can affect the relationship between urbanization and life satisfaction, and rural areas are at a disadvantage with respect to urban ones especially in poorer countries (Shucksmith et al. 2009, Easterlin et al. 2011, Berry, Okulicz-Kozaryn 2009, 2011, Requena 2015). These analyses have certainly advanced the understanding of spatial variations in life satisfaction and its determinants. However, a relatively neglected issue refers to the temporal dimension of these spatial unbalances, albeit with some exceptions (Ferrara, Nisticò 2015). In fact, it is not clear whether the disparities in life satisfaction are stable over time or they occur only in the presence of relevant gaps in the economic growth rates of urban and rural settings.

The aim of the present paper is to shed some light on these issues by drawing on fresh empirical evidence from Romania. After the end of the communist regime in 1990, 
Romania experienced a period of deep economic crisis, followed by a fast recovery, leading to the access to the EU in 2007. At the regional level, the growth patterns were highly differentiated. Urban areas always performed better than rural ones; from 2004 on, however, these imbalances widened even more. This was particularly true in the case of the capital city, Bucharest, whose rates of GDP growth outperformed all the other Romanian local economies. The evidence presented in the present paper is, therefore, aimed at understanding when these divergences among rural and urban areas of different size emerged and whether and how they mirrored (or not) on the life satisfaction of the resident population. By doing so, we are able to extend previous analyses on the Romanian case (Lenzi, Perucca 2016b) that highlighted important unbalances in life satisfaction across cities and an important penalty for the capital, Bucharest, in line with the original Easterlin's intuition and recent evidence by Piper (2015). In particular, while keeping the urban level of analysis, in this paper we exploit the longitudinal dimension of the large dataset on Romanian life satisfaction evolution and economic growth trends, in the period 1996-2011, that was not sufficiently examined in previous analyses; neither in cross-country studies, e.g. Okulicz-Kozaryn (2012), Rodríguez-Pose, Maslauskaite (2012), Lenzi, Perucca (2016a), nor in country specific studies, e.g., Andrén, Martinsson (2006), Mariana (2012), Lenzi, Perucca (2016b).

The discussion is organized as follows. In the next section, we discuss the literature on life satisfaction in transition countries and we present some evidence on the regional development patterns in Romania between 1995 and 2010. The third section describes the data set and the methodologies used in the analysis. The fourth section presents our findings, while in the final part we discuss conclusions.

\section{Life satisfaction and economic growth in Romanian regions}

\subsection{Life satisfaction in transition countries: a review of the literature}

In recent years, a long stream of research focused on the trends and determinants of individual life satisfaction. The main finding of this body of literature concerns the relationship between economic prosperity and self-reported wellbeing.

In one of the first works devoted to this issue, Easterlin (1995) pointed out two main results. The first one, consistent with the expectations of economic theory, is that richer individuals are happier than poor ones. The second, and counterintuitive, finding is that a further increase in income does not have any significant impact on life satisfaction. This conclusion, referred to as "Easterlin paradox" in the subsequent literature, was confirmed in a number of studies on developed countries, like US and Western European economies (Di Tella, MacCulloch 2008). The fall of the Iron Curtain, followed by a deep economic recession and, some years later, by a fast recovery, created ideal conditions to test whether the Easterlin paradox could be extended also to transition economies. Several works indeed addressed this issue.

From the paper by Blanchflower, Freeman (1997), a common finding of this literature indicates that life satisfaction in post-socialist countries was lower, for the whole period of transition and even at the end of it, than the one observed in developed western economies. Given the abovementioned evidence on the association between self-reported happiness and the absolute level of wealth, this result is consistent with the literature on the US and Western Europe (Lelkes 2006).

The relationship between life satisfaction and income growth patterns in transition economies is, on the other hand, less clear. For example, Sanfey, Teksoz (2007) focused on life satisfaction in a sample of transition countries between 1990 and 2002. Their findings pointed out the simultaneous decline of life satisfaction and GDP in the first years of transition, followed by a steady growth of both indicators in the second stage. As a result, in the early 2000's, almost all countries exhibited levels of self-reported happiness and GDP similar to the pre-transition ones. Evidence supporting the consistency of the association between the rise of life satisfaction and economic growth was found also by Guriev, Zhuravskaya (2009) in their study on 28 post-communist countries. RodríguezPose, Maslauskaite (2012) observed that the increase of life satisfaction over time in Eastern Europe was associated to economic growth only for some countries. Romania 
was among those. This last finding was confirmed also in the country-study by Andrén, Martinsson (2006). Taken together, these results seem to contradict the Easterlin paradox, at least as transition economies are concerned.

Easterlin et al. (2010), however, claimed that for those countries transitioning from socialism to capitalism, happiness and income go together only in the short term (i.e. for a period of no more than 10 years) while in the long period the Easterlin paradox still holds. Evidence supporting this claim was found by Easterlin, Plagnol (2008) in their analysis on life satisfaction in Eastern and Western Germany, and in a study focused on a set of post-communist countries by Easterlin (2009).

Another element that could help explain the common trajectories of happiness and GDP growth in transition economies is the role of urbanization. A broad amount of literature pointed out that the economic recovery of post-communist counties after the first phase of crisis was led by large urban areas and, in particular, capital cities (Kallioras, Petrakos 2010). Therefore, considering the trend of national GDP as a determinant of life satisfaction could be misleading, since it hides the variety of economic paths followed by different regions within the same country. Post-communist countries represent exemplary cases to test whether the association between urbanization and life satisfaction is likely to be particularly closely related in environments characterized by huge territorial disparities in terms of growth and urban expansion. In fact, urbanization is certainly related to positive externalities on individuals' wellbeing, such as better job opportunities, public services and amenities (Puga 2010), but it also generates agglomeration costs like pollution, congestion and social conflicts (Glaeser, Kahn 2010).

Some of the works summarized above incidentally found evidence of territorial imbalances in life satisfaction across settings marked by a different degree of urbanization. Interestingly, all these findings suggest that people living in rural settings are happier than those living in large cities (Rodríguez-Pose, Maslauskaite 2012). Similarly, Hayo (2007) claimed that residents in Bucharest are consistently less happy than those living in any other type of community. Likewise, Andrén, Martinsson (2006) pointed out that, again on the Romanian case, respondents living in the countryside are more likely to be happy than those in urban areas of any size. Finally, Mariana (2012) pointed out that life satisfaction in Romania mainly depends on the availability of resources satisfying the basic human needs.

More recently, Lenzi, Perucca (2016b) conducted a cross-sectional analysis on life satisfaction in Romanian regions, classified according to their level of urbanization, and found that the life satisfaction of residents in urban communities is higher than the happiness of those living in rural areas, with the sole exception of Bucharest. In this latter case, in fact, urban diseconomies prevail over the positive externalities of agglomeration, leading to lower levels of residents' well-being.

On balance, therefore, the literature has not yet achieved a definitive conclusion about the relationship between transition, urbanization and happiness. Moreover, little is known about the evolution of the relationship between life satisfaction and urbanization over time both in cross-country studies (e.g., Okulicz-Kozaryn 2012, Rodríguez-Pose, Maslauskaite 2012, Lenzi, Perucca 2016a) and in country specific studies (e.g., Andrén, Martinsson 2006, Mariana 2012, Lenzi, Perucca 2016b). The conjecture to be tested in the present paper is, then, that territorial differentials in well-being emerged when the development patterns and urbanization processes of different areas started to diverge. In the case of post-communist countries of Central and Eastern Europe, the most intense territorial divergence between urban and rural settings occurred in the second phase of transition and on the road to EU accession. Romania was not an exception in this respect and the next section will provide empirical evidence of economic growth in Romanian urban and rural regions. The focus on the Romanian case is related to two main reasons. First, this country includes several typologies of urban settlements, from very large cities (Bucharest) to second tier cities (e.g. Timisoara, Cluj), from third tier urban areas (e.g. Piatra Neamt, Arad) to rural communities. Second, survey data on residents' life satisfaction are available for a considerably long time span from 1996 to 2011 (Lenzi, Perucca 2016b) ${ }^{1}$.

\footnotetext{
${ }^{1}$ More details on the data set are available in Section 3.
} 


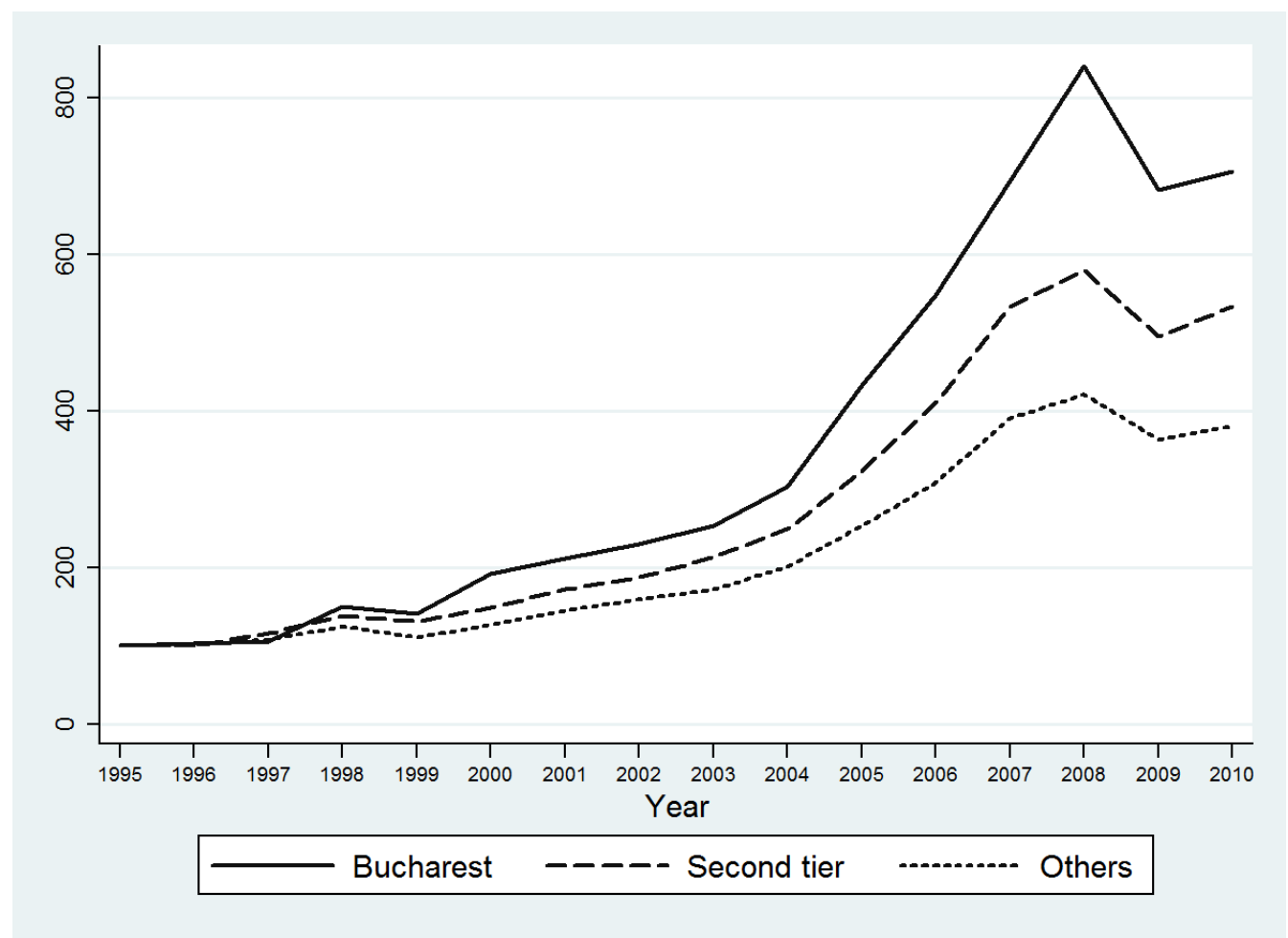

Figure 1: Per capita GDP growth in Romanian regions $(1995=100)$

Source: authors' own elaborations on data from the Romanian Institute of Statistics

2.2 Economic growth in Romanian regions: from the fall of the Iron Curtain to the EU accession

After the fall of the Iron Curtain, Romania experienced, as all the other post-communist countries, a period of strong economic recession. According to the World Bank ${ }^{2}$, Romanian per capita GDP in real prices was equal in 1995 to the 85 per cent of its value in 1989. Only in 2003, Romania reached again the pre-transition levels. Within Romania, the growth path was highly differentiated across different typologies of regions.

Figure 1 reports the per capita GDP growth rate of different groups of Romanian NUTS3 regions classified according to the population living in the largest city. Bucharest is a unique case in the national context, with 2.3 (in 1995) million inhabitants living in the urban area. The second category comprehends those regions characterized by the presence of a second tier city, i.e. a city with more than 200,000 residents. Finally, NUTS3 areas including towns with less than 200,000 inhabitants are in the third group.

Figure 1 shows that the first years (1995-1999) were characterized by modest divergences in GDP growth across the three typologies of regions. The gap started to widen from 2000 on, even if, in the short run, it remained relatively moderate. From 2004 on, the year of the accession to the EU of other eight Eastern European countries, the differentials in economic growth for the three groups of regions increased more and more ${ }^{3}$. As a result, the relative weight of urban and rural regions on the overall Romanian economy significantly changed, as shown in Figure 2. In 1995, Bucharest contributed to national GDP for a share of about 15 per cent. Fifteen years later, it accounted for one quarter of the yearly domestic product. In addition, regions dominated by a second tier city experienced a growth of their relative relevance within the country, even if to a lower extent than the capital (from 9.7 to 11.5 per cent). Finally, regions without any large urban areas are marked by a sharp decrease of their share of GDP compared with the

\footnotetext{
${ }^{2}$ Source: http://data.worldbank.org/indicator/NY.GDP.MKTP.KD

${ }^{3}$ The accession Treaty was signed in April 2005, when both Bulgaria and Romania obtained the status of acceding country. The accession of these countries was initially planned for 2004 but Romania and Bulgaria actually joined the EU in 2007. The European Commission officially considers the 2007 enlargement as part of the 2004 one.
} 
rest of the country, falling from 75.4 per cent in 1995 to 63.4 in 2010 . The most intense divergences across these three groups of regions occurred between 2004 and 2008, while relative stability characterized the years of economic crisis (2008-2010).

Lenzi, Perucca $(2016 a, b)$ provide complementary evidence about the divergence in life satisfaction across cities of different size but without exploring the temporal dimension of these unbalances and their emergence. The analysis of the present paper, then, tries to supplement previous evidence by advancing an interpretation of the spatial and temporal trends of life satisfaction by taking advantage of the concept of urbanization externalities. In fact, as pointed out in the literature on agglomeration economies (Glaeser 2011), the positive economic externalities generated by large cities in the form of job opportunities and higher income are significantly greater than the ones arising in smaller urban areas. Larger and denser cities tend to show greater productivity and wages, as well as to offer wider opportunities for learning and knowledge exchanges, innovation and creativity. Moreover, public services and amenities that may positively influence life satisfaction (see for reviews Rosenthal, Strange 2004, Puga 2010) tend to be supplied in larger quantities in larger cities. On the other hand, increased city size and population density can show characteristics that can reduce life satisfaction. Land rent is higher (Partridge et al. 2009), and, by consequence, the cost of living (Dijkstra et al. 2013) increases. Environmental problems are exacerbated, such as congestion and pollution (Glaeser, Kahn 2008) and unregulated urban expansion (Glaeser, Kahn 2004), as well as social conflict and malaise (Glaeser, Sacerdote 1999) ${ }^{4}$. Yet, as far as positive and negative externalities grow similarly across different types of urban settings, we may expect a substantially neutral effect of city size on life satisfaction. This may the case of in the years characterized by limited disparities in growth patterns across different urban areas (i.e. between 1995 and 2004). Differently, we may expect that the fast and heterogeneous growth of urban areas on the road to EU accession (from 2004 on), possibly driven by unbalanced positive and negative urbanization externalities, widened the gap in life satisfaction of residents in rural and cities of different size. The next sections try to shed some lights on these possible trends.

\section{Data and methods}

\subsection{Data on life satisfaction in Romania}

The empirical analysis draws on a dataset pulling together several Eurobarometer survey waves. Since 1973, these surveys have been conducted on behalf of the European Commission with the aim of monitoring public opinion on multiple issues, such as EU citizens' self-reported well-being.

From 1990 Eurobarometer opinion polls were carried out also in the New Member Countries, initially under the label "Central and Eastern Eurobarometer" (1990-1997) and then as part of the "Candidate Countries Eurobarometer Series" (1998-2004). After the first EU enlargement in May 2004 surveys on CEECs were integrated in the "Standard and Special Eurobarometer Series".

However, the questionnaire wording is not always consistent across different studies. In particular, for Romania, availability and comparability of data is limited to the periods 1996-1998 and 2001-20105.

The final dataset has been obtained by pooling different cross sectional studies over time and includes over 24,000 records on subjective well-being at the individual level, together with information on some individual characteristics. The literature largely emphasizes the role played by individual factors on life satisfaction (Frey, Stutzer 2000); consequently, the empirical analysis will consider them as discussed in the next section.

\footnotetext{
${ }^{4}$ This point is similarly discussed in Lenzi, Perucca (2016b).

${ }^{5}$ More in details, the survey waves employed in the present paper are the following ones. For the period 1996-1998 data come from the collection "Studies from Eastern Europe - Quality of life diagnosis in Romania", edition 1996 (ZA3645), 1997 (ZA3646) and 1998 (ZA3647). Between 2001 and 2003 data are provided by the surveys from the series "Candidate Countries Eurobarometer Series", edition 2001 (ZA3978), 2002 (ZA4153 and ZA3979) and 2003 (ZA3986 and ZA3983). Finally, for the other years data are available from the "Standard and Special Eurobarometer Series", edition 2004 (ZA4229 and ZA4231), 2005 (ZA4411 and ZA4414), 2006 (ZA4506 and ZA4526), 2007 (Z4530 and ZA4565), 2008 (ZA4744 and ZA4819), 2009 (ZA4971, ZA4972 and ZA4973), 2010 (ZA5234, ZA5235 and ZA5449).
} 


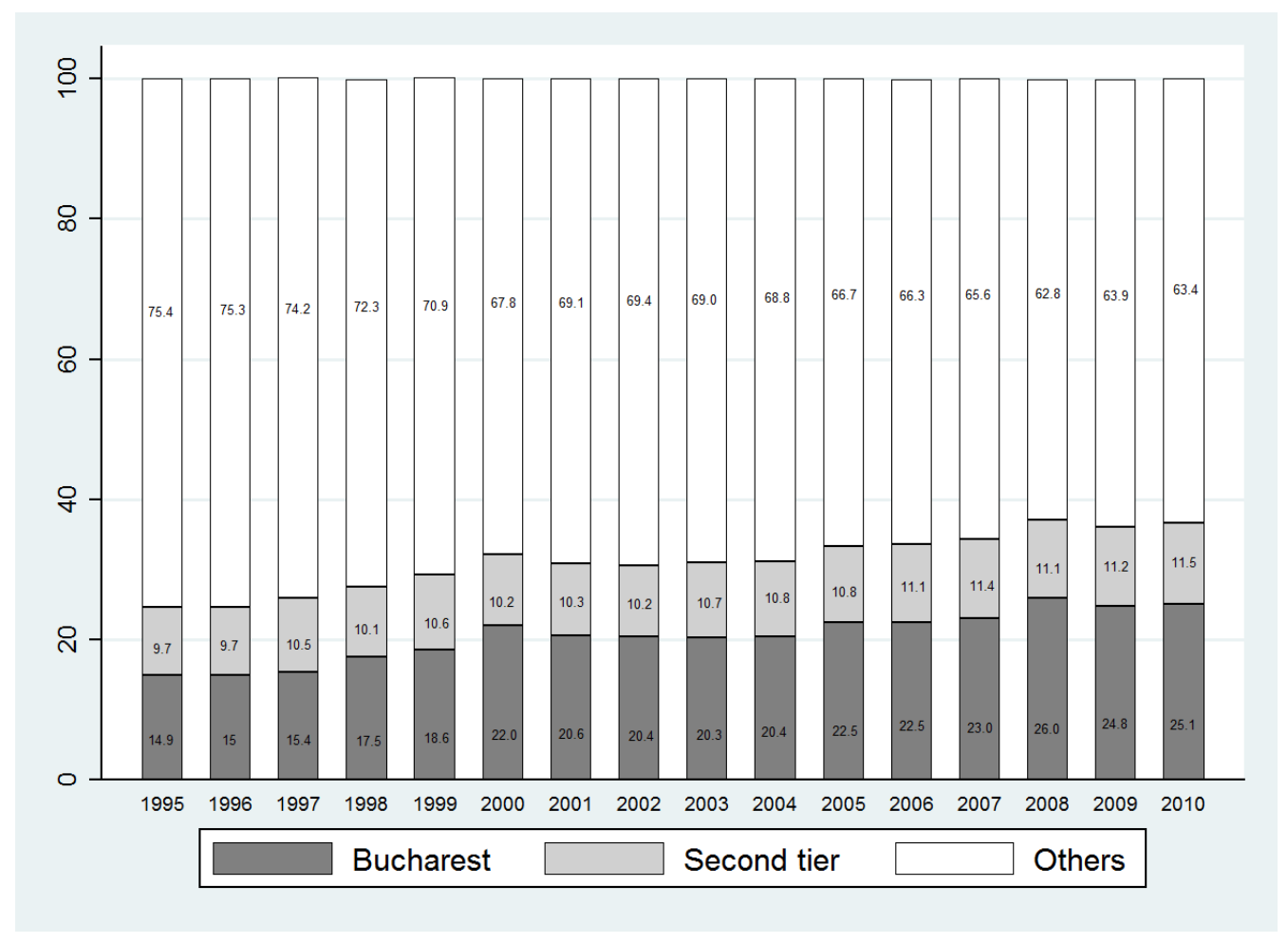

Figure 2: Share of national GDP by different typologies of NUTS3 regions Source: authors' own elaborations on data retrieved from the Romanian Institute of Statistics

\subsection{The empirical model}

The empirical model aims at testing the relevance of agglomeration economies on life satisfaction over time while controlling for additional determinants of life satisfaction identified in the literature.

In particular, the effect of city size (i.e. the proxy used for urbanization and agglomeration) on life satisfaction is captured through a set of dummy variables, one for each of the four categories considered. In fact, Eurobarometer surveys ask respondents to indicate the size of the community they live in by choosing from alternative options: less than 100,000 residents (small cities and rural areas), 100,000-200,000 residents (medium cities), more than 200,000 residents (apart from Bucharest, large cities), Bucharest ${ }^{6}$. The answer to this question has been used to capture the possible effects of urbanization generated by the spatial agglomeration of activities and individuals in cities ${ }^{7}$.

Besides the dummy variables accounting for city size, the empirical models include several control variables, as suggested by recent reviews on the determinants of life satisfaction (Frey, Stutzer 2000, Dolan et al. 2008, Blanchflower, Oswald 2011). Data availability and comparability across all years considered largely constrained their selection.

At the individual level, the control variables considered are the respondent's age, gender, education, family status, and occupation. ${ }^{8}$. Existing literature indicates some stylized facts about the relationship between individual characteristics and life satisfaction (Dolan et al. 2008, Blanchflower, Oswald 2011). In terms of age, the literature suggests that the relationship between age and happiness is U-shaped (with minimum around

\footnotetext{
${ }^{6}$ It is worth remarking that in Romania there are several large cities $(>200,000$ inhabitants) but none of them achieves a population greater than 350,000 whereas Bucharest has a population of about 2 million inhabitants (Source: Romanian National Institute of Statistics, Census 2011).

${ }^{7}$ A fuller discussion of the advantages of this categorization is presented in Lenzi, Perucca (2016b).

${ }^{8}$ In the 1996, 1997, 1998 surveys age was coded into 6 categories. For comparability reasons, therefore, we recoded the continuous age variable available in the other Eurobarometer surveys according to this six-point scale. Additional controls at the individual level, such as vote intention, religion, trust, health were excluded because of the limited comparability of the questionnaires over time.
} 
Table 1: Data description

\begin{tabular}{|c|c|c|c|}
\hline Name & Description & Source & Year \\
\hline Community size & $\begin{array}{l}\text { Size of the city of the respondent (number of } \\
\text { inhabitants): Less than 100,000 inhabitants, } \\
\text { 100,000-200,000 inhabitants, more than 200,000 } \\
\text { inhabitants (apart from Bucharest), Bucharest; } \\
\text { reference category: less than } 100,000 \text { inhabitants }\end{array}$ & Eurobarometer & $\begin{array}{l}1996-1998 ; \\
2001-2010\end{array}$ \\
\hline Gender & Gender of the respondent; reference category: male & Eurobarometer & $\begin{array}{l}1996-1998 ; \\
2001-2010\end{array}$ \\
\hline Age & $\begin{array}{l}\text { Age of the respondent: coded into six categories, } \\
\text { under } 20,21-30,31-40,41-50,51-60 \text {, over } 60 \\
\text { reference category: under } 20\end{array}$ & Eurobarometer & $\begin{array}{l}1996-1998 ; \\
2001-2010\end{array}$ \\
\hline Education & $\begin{array}{l}\text { Level of education of the respondent according to } \\
\text { the ISCED classification. Low education=ISCED } \\
\text { 1-2, medium education=ISCED 3-4, high education } \\
=\text { ISCED 5-6; reference category: low education }\end{array}$ & Eurobarometer & $\begin{array}{l}1996-1998 ; \\
2001-2010\end{array}$ \\
\hline Occupation & $\begin{array}{l}\text { Occupation of the respondent: non-working, } \\
\text { student, employed, self-employed; reference } \\
\text { category: non-working }\end{array}$ & Eurobarometer & $\begin{array}{l}1996-1998 ; \\
2001-2010\end{array}$ \\
\hline Marital status & $\begin{array}{l}\text { Marital status of the respondent: single, married, } \\
\text { divorced, widowed; reference category: single }\end{array}$ & Eurobarometer & $\begin{array}{l}1996-1998 ; \\
2001-2010\end{array}$ \\
\hline Per capita GDP & Per capita GDP in the NUTS2 region of residence & Eurostat & $\begin{array}{l}1996-1998 ; \\
2001-2010\end{array}$ \\
\hline
\end{tabular}

30-50 years, depending on the study); in fact, younger people tend to be happier than adults are but elder people as well are happier than adults are. The effect of age is captured by six dummy variables each accounting for a different age class (under 20 year old (the reference category in all estimations); 21-30 old; 31-40 old; 41-50 old; 51-60 old; over 60 old). In addition, women are generally more satisfied with their lives than men are $^{9}$. The effect of gender is captured through a dummy variable taking value 1 if the respondent is female and 0 if he is male (which is the reference category in all estimations). Moreover, greater educational levels are associated to higher life satisfaction, especially in lower income countries, despite its effect can be influenced by the introduction of other variables as education often reflects also unobservable traits at the individual level such as motivation, intelligence or family background. The effect of education has been captured by three dummy variables each accounting for a different educational attainment level according to the ISCED classification (ISCED 1-2: low education (the reference category in all estimations); ISCED 3-4: medium education; ISCED 5-6: high education). Empirical evidence also suggests that married people are the happiest and divorced the least happy. The effect of marital status has been captured by four dummy variables each accounting for a different status (married, divorced, widowed, single [the reference category in all estimations]). Finally, being employed is found consistently and significantly associated with higher subjective well-being. The effect of occupation has been captured by four dummy variables each accounting for a different occupational status (non-working, employed, self-employed, student [the reference category in all estimations]).

In absence of data on income at the individual level for all waves, per capita GDP in the respondent's NUTS2 region of residence is used as an alternative proxy. The literature, in fact, reports that income is an important determinant of individual happiness (Easterlin 1995). The effect of income is expected to raise self-reported happiness; however, the relationship between income and happiness can be more complex and a quadratic term is introduced to control for possible decreasing returns detected in some studies, as indicated in the literature (Blanchflower, Oswald 2011) ${ }^{10}$.

Table 1 provides a summary of the variables described above and their sources.

\footnotetext{
${ }^{9}$ The statistical significance of this effect is less stable and frequently vanishes when other control variables are included.

${ }^{10}$ For example, Rodríguez-Pose, Maslauskaite (2012) report that happiness is more influenced by relative income than by absolute income.
} 
Finally, the empirical analysis includes year dummies. Their relevance is particularly high in the present context. First, these variables can control for the evolution over time of nation-wide phenomena in terms of both social and economic institutional conditions, and of macroeconomic factors at national level, as for instance the inflation rate, assumed to be homogeneous across the country. Second, they can account for the deep socio-economic changes that affected Romania in the period considered, most notably the transition from planned to market economy, the preparation for entry and the final accession into the EU, and, lastly, the impact of the financial and public debt crisis, most of which deeply interacted with the operation of urbanization and agglomeration forces. By the use of time dummies we are able to shed further light on the relationship between urbanization, life satisfaction and economic performance. In particular, following the discussion in Section 2 , the early years after accession are expected to be characterized by lower levels of life satisfaction, which is instead expected to grow steadily in the years around accession to the European Union, with some decline in the years of the crisis.

The measurement of the dependent variable is based on the Eurobarometer question asking respondents to indicate their level of life satisfaction among four options: very satisfied, rather satisfied, fairly dissatisfied or very dissatisfied. In this paper, self-reported level of satisfaction has dichotomized; the deriving dummy variable takes a value of 1 if the individual is very or rather satisfied and equal to 0 otherwise.

Therefore, the empirical model to be estimated for any individual $i$ in any NUTS2 $r$ is as follows:

$$
\begin{aligned}
P(\text { Life satisfaction }=1)= & F\left(\text { age }_{i}, \text { gender }_{i}, \text { marital status }_{i}, \text { education }_{i}, \text { occupation }_{i},\right. \\
& \text { per capita GDP } \\
r & \left., \text { city size }_{i}, \text { year dummy }\right)
\end{aligned}
$$

This model has been estimated by logit. In principle, the ordinal nature of the dependent variable would require the estimation of an ordered model, such as ordered logit or probit. However, the estimation of a binary logit can be defended on the ground of two main arguments. First, ordered models are based on the assumption that the relationship between different categories of the dependent variable is always the same. This hypothesis has been rejected by means of Brant tests implemented on each single variable (as shown in Appendix A.1). Alternatively, multinomial models could be used. The latter, on the other hand, have a less straightforward interpretation since it would produce, in the present empirical study, a set of coefficients for each regressor and make more complex the identification of the overall impact of urban agglomeration on subjective well-being, which is main issue of the paper. Yet, the main conclusions of the analysis are robust to the estimation of ordered logit models (as shown in Appendix A.1), where the probability of satisfaction is measured on a four-item satisfaction scale. Lastly, in all regressions, errors are clustered at both the year and regional (NUTS2) level.

\section{Results}

Table 2 shows the estimates of Equation 1 and reports adapted results from Lenzi, Perucca (2016b). Individual characteristics largely show the expected sign and significance consistent with stylized facts in the literature, confirming their relevance as determinants of life satisfaction ${ }^{11}$. Given the high consistency of estimates with existing results, the coefficient of individual variables are not displayed with the exception of regional (NUTS2) GDP per capita, our proxy for individual wealth; its influence on life satisfaction follows an inverted U-shaped form suggesting positive though diminishing returns on life satisfaction $^{12}$. More interestingly, the dummy variables accounting for the population size of the residence area are not significant (Table 2, model 2), with the exception of

\footnotetext{
${ }^{11}$ The full set of individual effects coefficients is available and commented in Appendix A.2.

${ }^{12} \mathrm{We}$ are aware that GDP per capita is an indirect proxy for income. Unfortunately, data on income at NUTS2 are available only for a shorter period (i.e. from 2000 onwards). Yet, the simple correlation between GDP per capita and income (computed on those years in which data are available at NUTS2 level) is 0.92 and significant at 1\% level. By substituting GDP per capita with income and running regressions on the subsample for which income data are available, findings are qualitatively unchanged. Appendix A.3 reports the results of this robustness check. Therefore, given the high consistency of
} 
Table 2: Life satisfaction and city size

\begin{tabular}{|c|c|c|c|}
\hline Dependent variable: satisfied/very satisfied $=1$ & $(1)$ & $(2)$ & $(3)$ \\
\hline Per capita GDP & $\begin{array}{l}0.488^{* * *} \\
(0.086)\end{array}$ & $\begin{array}{l}0.503^{* * *} \\
(0.093)\end{array}$ & $\begin{array}{l}0.477^{* * *} \\
(0.083)\end{array}$ \\
\hline Per capita GDP (square) & $\begin{array}{l}-0.022^{* * *} \\
(0.004)\end{array}$ & $\begin{array}{l}-0.023^{* * *} \\
(0.005)\end{array}$ & $\begin{array}{l}-0.021^{* * *} \\
(0.004)\end{array}$ \\
\hline \multicolumn{4}{|c|}{ Community size (ref.: less than 100,000 residents) } \\
\hline $100-200,000$ residents & & $\begin{array}{l}0.106^{* * *} \\
(0.036)\end{array}$ & $\begin{array}{l}0.107^{* * *} \\
(0.034)\end{array}$ \\
\hline$>200,000$ residents & & $\begin{array}{c}0.082 \\
(0.070)\end{array}$ & \\
\hline$>200,000$ residents (without Bucharest) & & & $\begin{array}{l}0.130^{* *} \\
(0.057)\end{array}$ \\
\hline Bucharest & & & $\begin{array}{l}-0.103^{* * *} \\
(0.036)\end{array}$ \\
\hline \multicolumn{4}{|l|}{ Year dummies (ref.: 1996) } \\
\hline 1997 & $\begin{array}{l}-0.196^{* * *} \\
(0.055)\end{array}$ & $\begin{array}{l}-0.197^{* * *} \\
(0.054)\end{array}$ & $\begin{array}{l}-0.195^{* * *} \\
(0.052)\end{array}$ \\
\hline 1998 & $\begin{array}{l}-0.176^{* * *} \\
(0.006)\end{array}$ & $\begin{array}{l}-0.175^{* * *} \\
(0.006)\end{array}$ & $\begin{array}{l}-0.177^{* * *} \\
(0.006)\end{array}$ \\
\hline 2001 & $\begin{array}{l}0.694^{* * *} \\
(0.074)\end{array}$ & $\begin{array}{l}0.693^{* * *} \\
(0.076)\end{array}$ & $\begin{array}{l}0.689^{* * *} \\
(0.073)\end{array}$ \\
\hline 2002 & $\begin{array}{l}0.895^{* * *} \\
(0.113)\end{array}$ & $\begin{array}{l}0.895^{* * *} \\
(0.112)\end{array}$ & $\begin{array}{l}0.892^{\text {*** }} \\
(0.112)\end{array}$ \\
\hline 2003 & $\begin{array}{l}0.607^{* * *} \\
(0.069)\end{array}$ & $\begin{array}{l}0.574^{* * *} \\
(0.077)\end{array}$ & $\begin{array}{l}0.642^{* * *} \\
(0.065)\end{array}$ \\
\hline 2004 & $\begin{array}{l}0.756^{* * *} \\
(0.091)\end{array}$ & $\begin{array}{l}0.760^{* * *} \\
(0.091)\end{array}$ & $\begin{array}{l}0.764^{* * *} \\
(0.089)\end{array}$ \\
\hline 2005 & $\begin{array}{l}0.396^{* * *} \\
(0.015)\end{array}$ & $\begin{array}{l}0.398^{* * *} \\
(0.005)\end{array}$ & $\begin{array}{l}0.396^{* * *} \\
(0.005)\end{array}$ \\
\hline 2006 & $\begin{array}{l}0.378^{* * *} \\
(0.106)\end{array}$ & $\begin{array}{l}0.377^{* * *} \\
(0.106)\end{array}$ & $\begin{array}{l}0.385^{* * *} \\
(0.101)\end{array}$ \\
\hline 2007 & $\begin{array}{l}0.489^{* * *} \\
(0.087)\end{array}$ & $\begin{array}{l}0.486^{* * *} \\
(0.087)\end{array}$ & $\begin{array}{l}0.497^{* * *} \\
(0.077)\end{array}$ \\
\hline 2008 & $\begin{array}{l}0.374^{* * *} \\
(0.096)\end{array}$ & $\begin{array}{l}0.370^{* * *} \\
(0.097)\end{array}$ & $\begin{array}{l}0.383^{* * *} \\
(0.090)\end{array}$ \\
\hline 2009 & $\begin{array}{l}0.396^{* * *} \\
(0.091)\end{array}$ & $\begin{array}{l}0.392^{* * *} \\
(0.090)\end{array}$ & $\begin{array}{l}0.403^{* * *} \\
(0.083)\end{array}$ \\
\hline 2010 & $\begin{array}{l}-0.187^{* * *} \\
(0.059)\end{array}$ & $\begin{array}{l}-0.191^{* * *} \\
(0.059)\end{array}$ & $\begin{array}{l}-0.180^{* * *} \\
(0.048)\end{array}$ \\
\hline Constant & $\begin{array}{l}-1.974^{* * *} \\
(0.092)\end{array}$ & $\begin{array}{l}-2.021^{* * *} \\
(0.118)\end{array}$ & $\begin{array}{l}-1.968^{* * *} \\
(0.102)\end{array}$ \\
\hline Individual characteristics & Yes & Yes & Yes \\
\hline Regional dummies & Yes & Yes & Yes \\
\hline Observations & 24,146 & 24,146 & 24,146 \\
\hline
\end{tabular}


those living in intermediate towns with 100-200,000 residents, who are more satisfied than residents of other settlement categories, similarly to findings reported by Rodríguez-Pose, Maslauskaite (2012). This result indicate that people living in large cities are as happy as those living in less populated and rural areas. However, on separating out the effect of the capital city (Bucharest) from that of the other large cities, i.e. cities with more than 200,000 inhabitants (Table 2, model 3), the picture becomes more nuanced. In fact, results indicate that people living in these areas are happier than those residing in less populated areas, suggesting the existence of an urban-rural divide in life satisfaction favoring relatively larger cities (with more than 100,000 residents), consistent with findings by Mariana (2012). On the other hand, living in the capital city is detrimental to life satisfaction, consistent with findings by Piper (2015). With the exception of Bucharest, therefore, Romanian people living in larger cities seem happier than the others are.

Possibly, the unexpected result for Bucharest can be read through the concept of agglomeration economies/diseconomies. In particular, the presence of greater congestion costs, pollution, social conflicts, crime rates, labor crowding, living costs and reduced purchasing power can make the capital city less attractive with respect to other large cities in the country. Above a certain threshold, increased population size seems to provide more disadvantages than advantages and agglomeration costs seem to prevail over agglomeration benefits, as may be the case of Bucharest. Finally, coming to the time dummies, life satisfaction has rapidly grown in the years close to accession; this pattern has been rather stable, with a decline in 2010 at the peak of the European financial and public debt crisis. Nonetheless, even during the crisis, life satisfaction was greater than in late 1990s, when the transition phase was not yet completed, as similarly found by Sanfey, Teksoz (2007).

In order to understand better the impact of transition over time and space, we repeated this set of regressions by splitting the sample in two periods. The first one includes the final phase (1995-2004) of post-communist transition. The second period comprehends the years immediately before and after EU accession (2004-2010).

Interestingly, results for the first period (Table 3) indicate that the role of per capita regional GDP for life satisfaction was negligible and the unfolding of positive agglomeration effects was not yet reached. Rather, urbanization economies have a non-significant or even negative effect (in the case of Bucharest and of cities between 100 and 200,000 residents). This can be related to the fact that, in this phase, Romanian cities were not characterized by huge gaps, in terms of economic growth, compared with the countryside. Consequently, the negative urban externalities like the higher costs of living, congestion and pollution, were not fully counterbalanced by the economic benefits specific of urban areas. Interestingly, Bucharest was also the region characterized by the most intense growth of GDP in the period analyzed. To further prove this point, Table 4 shows the results from an Analysis of variance (ANOVA) on both the average level of satisfaction (measured as ratio between satisfied respondents over unsatisfied ones) and the per capita GDP growth rate by different typologies of NUTS3 regions, i.e. the four groups of communities considered above ${ }^{13}$. Interestingly, GDP per capita growth rate in the period considered does not significantly differ across groups of regions of different size, with the exception of Bucharest. Therefore, the economic growth occurred in the capital city was not associated with higher levels of life satisfaction. Instead, after having controlled for individual characteristics and for the overall level of wealth, the pure effect of city size on life satisfaction becomes negative (Table 3$)^{14}$.

findings obtained by using the two variables, we opted for the largest temporal coverage and used GDP per capita data.

On a purely theoretical ground, we cannot exclude endogeneity concerns in the form of sorting effects, i.e. satisfied people are more likely to move to happier/wealthier cities. This issue is discussed in depth in the companion paper Lenzi, Perucca (2016b), reporting no substantial evidence of endogeneity and sorting effects, albeit using a different dataset enabling a direct comparison of life satisfaction between natives and migrants. The present dataset, unfortunately, does not allow recording such information in a longitudinal way, even if we are aware that it would add robustness to our findings. In absence of a direct statistical test excluding the presence of endogeneity, however, our estimates are better to be interpreted as robust partial correlation coefficients rather than causally.

${ }^{13}$ NUTS3 regions are classified according to the resident population in their largest city.

${ }^{14}$ Notice that in Table 4 the average level of satisfaction in Bucharest is not significantly lower than in 
Table 3: Life satisfaction and city size: 1996-2004

\begin{tabular}{|c|c|c|c|}
\hline Dependent variable: satisfied/very satisfied $=1$ & (1) & $(2)$ & $(3)$ \\
\hline Per capita GDP & $\begin{array}{l}-0.137 \\
(0.258)\end{array}$ & $\begin{array}{l}-0.112 \\
(0.258)\end{array}$ & $\begin{array}{l}-0.103 \\
(0.234)\end{array}$ \\
\hline Per capita GDP (square) & $\begin{array}{l}0.014 \\
(0.025)\end{array}$ & $\begin{array}{c}0.013 \\
(0.025)\end{array}$ & $\begin{array}{c}0.014 \\
(0.024)\end{array}$ \\
\hline \multicolumn{4}{|c|}{ Community size (ref.: less than 10,000 residents) } \\
\hline 100-200,000 residents & & $\begin{array}{l}-0.100^{* *} \\
(0.048)\end{array}$ & $\begin{array}{l}-0.099^{* *} \\
(0.048)\end{array}$ \\
\hline$>200,000$ residents & & & $\begin{array}{l}-0.028 \\
(0.075)\end{array}$ \\
\hline$>200,000$ residents (without Bucharest) & & $\begin{array}{l}-0.120 \\
(0.076)\end{array}$ & \\
\hline Bucharest & & & $\begin{array}{l}-0.236^{* * *} \\
(0.050)\end{array}$ \\
\hline \multicolumn{4}{|l|}{ Year dummies (ref.: 1996) } \\
\hline 1997 & $\begin{array}{l}-0.149^{* * *} \\
(0.032)\end{array}$ & $\begin{array}{l}-0.151^{* * *} \\
(0.041)\end{array}$ & $\begin{array}{l}-0.153^{* * *} \\
(0.046)\end{array}$ \\
\hline 1998 & $\begin{array}{l}-0.214^{* * *} \\
(0.012)\end{array}$ & $\begin{array}{l}-0.212^{* * *} \\
(0.012)\end{array}$ & $\begin{array}{l}-0.213^{* * *} \\
(0.011)\end{array}$ \\
\hline 2001 & $\begin{array}{l}0.542^{* * *} \\
(0.118)\end{array}$ & $\begin{array}{l}0.551^{* * *} \\
(0.123)\end{array}$ & $\begin{array}{l}0.553^{* * *} \\
(0.123)\end{array}$ \\
\hline 2002 & $\begin{array}{l}0.817^{* * *} \\
(0.118)\end{array}$ & $\begin{array}{l}0.820^{* * *} \\
(0.122)\end{array}$ & $\begin{array}{l}0.818^{* * *} \\
(0.122)\end{array}$ \\
\hline 2003 & $\begin{array}{l}0.615^{* * *} \\
(0.093)\end{array}$ & $\begin{array}{l}0.660^{* * *} \\
(0.103)\end{array}$ & $\begin{array}{l}0.693^{* * *} \\
(0.098)\end{array}$ \\
\hline 2004 & $\begin{array}{l}0.931^{* * *} \\
(0.076)\end{array}$ & $\begin{array}{l}0.916^{* * *} \\
(0.073)\end{array}$ & $\begin{array}{l}0.905^{* * *} \\
(0.077)\end{array}$ \\
\hline Constant & $\begin{array}{l}-0.532 \\
(0.644)\end{array}$ & $\begin{array}{l}-0.569 \\
(0.642) \\
\end{array}$ & $\begin{array}{l}-0.611 \\
(0.588)\end{array}$ \\
\hline Individual characteristics & Yes & Yes & Yes \\
\hline Regional dummies & Yes & Yes & Yes \\
\hline Observations & 9,935 & 9,935 & 9,935 \\
\hline
\end{tabular}

On the other hand, results for the second period (Table 5) describe a very different situation. First, life satisfaction begins responding to economic conditions and incentives. Regional (NUTS2) per capita GDP shows a statistically significant and inverted U-shaped effect on life satisfaction (consistent with the literature and Table 1). Second, cities of more than 100,000 inhabitants seem to offer better opportunities and contexts to achieve greater individual life satisfaction with respect to less populated and rural areas. As commented above, Bucharest represents an exception to this pattern and seems characterized by negative agglomeration effects in both periods. The ANOVA results on the average level of satisfaction between 2004 and 2010 and on the change in GDP occurred in the same period are shown in Table 4. Again, as far as GDP per capita growth is concerned, Bucharest outperforms the other groups of regions. In absence of any individual and wealth control, Bucharest is characterized by a level of life satisfaction higher than the one of regions with less than 100,000 inhabitants (Table 4). However, once taking into account all the individual and regional factors described in Table 1, the net effect of the urbanization economies of the capital city appears to be negative (Table 5). Therefore,

the other regions. Nevertheless, in this case we are not accounting for any of the other controls included in Table 3. 
Table 4: Per capita GDP growth rate and life satisfaction by different typologies of NUTS3 regions: ANOVA results

\begin{tabular}{|c|c|c|c|c|}
\hline \multicolumn{5}{|c|}{ 1996-2004 } \\
\hline & \multicolumn{2}{|c|}{ Group means } & \multicolumn{2}{|c|}{ Pairwise comparisons } \\
\hline Community size & $\begin{array}{l}\Delta \text { per capita } \\
\text { GDP }\end{array}$ & $\begin{array}{l}\text { Satisfied/ } \\
\text { unsatisfied } \\
\text { respondents }\end{array}$ & \multirow{5}{*}{$\begin{array}{c}\Delta \text { per capita } \\
\text { GDP } \\
\text { Not } \\
\text { significant } \\
\text { Not } \\
\text { significant } \\
\text { Not } \\
\text { significant } \\
+ \text { [all other } \\
\text { groups] }\end{array}$} & \multirow{5}{*}{$\begin{array}{c}\text { Satisfied/ } \\
\text { unsatisfied } \\
\text { respondents } \\
\text { Not } \\
\text { significant } \\
\text { Not } \\
\text { significant } \\
\text { Not } \\
\text { significant } \\
\text { Not } \\
\text { significant }\end{array}$} \\
\hline$<100,000$ & 1.083 & 0.386 & & \\
\hline $100-200,000$ & 1.094 & 0.368 & & \\
\hline $\begin{array}{l}>200,000 \\
\text { (w/o Bucharest) }\end{array}$ & 1.167 & 0.394 & & \\
\hline Bucharest & 1.582 & 0.357 & & \\
\hline $\mathrm{F}$ & $7.70^{* * *}$ & $2.14^{*}$ & & \\
\hline \multicolumn{5}{|c|}{$2004-2010$} \\
\hline & \multicolumn{2}{|c|}{ Group means } & \multicolumn{2}{|c|}{ Pairwise comparisons } \\
\hline Community size & $\begin{array}{l}\Delta \text { per capita } \\
\text { GDP }\end{array}$ & $\begin{array}{l}\text { Satisfied/ } \\
\text { unsatisfied } \\
\text { respondents }\end{array}$ & $\begin{array}{l}\Delta \text { per capita } \\
\text { GDP }\end{array}$ & $\begin{array}{l}\text { Satisfied/ } \\
\text { unsatisfied } \\
\text { respondents }\end{array}$ \\
\hline$<100,000$ & 1.117 & 0.426 & $\begin{array}{c}\text { Not } \\
\text { significant }\end{array}$ & $-[$ Bucharest $]$ \\
\hline $100-200,000$ & 1.058 & 0.532 & $\begin{array}{c}\text { Not } \\
\text { significant }\end{array}$ & $+[<100,000]$ \\
\hline $\begin{array}{l}>200,000 \\
\text { (w/o Bucharest) }\end{array}$ & 1.169 & 0.563 & $\begin{array}{l}\text { Not } \\
\text { significant }\end{array}$ & $\begin{array}{c}+[<100,000 \\
\text { and Bucharest }]\end{array}$ \\
\hline Bucharest & 1.337 & 0.504 & $\begin{array}{c}+[<100,000 \text { and } \\
100-200,000]\end{array}$ & $\begin{array}{c}+[<100,000], \\
-[>200,000(\mathrm{w} / \mathrm{o} \\
\text { Bucharest) }]\end{array}$ \\
\hline $\mathrm{F}$ & $4.66^{* * *}$ & $75.66^{* * *}$ & & \\
\hline
\end{tabular}

Source: authors' own elaborations

even if high levels of wealth would lead to a positive payoff in terms of life satisfaction, the purely economic advantages are offset by negative effect on life satisfaction of living in a congested and socially insecure environment.

Finally, we tried to establish a link, if any, between the analysis of the relationship between change in life satisfaction and wealth over time and the main results from the literature on self-reported well-being claiming that economic growth is not associated with significant changes in life satisfaction (Easterlin 1995). In particular, Figure 3 shows the plot of the coefficients of the year dummies reported in Table 3 and Table 5, respectively for the period 1996-2004 and for 2004-2010, associated with the change in per capita GDP that occurred in Romania with respect to the reference years (respectively 1996 and 2004 for the two periods). It is worth noting that between 1996 and 2004 the year dummies and the average growth in per capita GDP follow a very similar pattern, as reported by Sanfey, Teksoz (2007), Guriev, Zhuravskaya (2009), Easterlin et al. (2010). Compared to 1996, the following two years of economic slowdown are associated with a decrease in life satisfaction. The opposite holds for the following years (2001-2004) of economic recovery, even if the differences between the estimated coefficients are, in this case, weakly significant. A different scenario characterizes the second period, between 2004 and 2010. In this case, in fact, the intense economic growth occurred until 2009 is not mirrored by the estimate coefficients of the time dummies. This happens only at the 
Table 5: Life satisfaction and city size: 2004-2010

\begin{tabular}{|c|c|c|c|}
\hline Dependent variable: satisfied/very satisfied $=1$ & (1) & (2) & (3) \\
\hline Per capita GDP & $\begin{array}{l}0.238^{* * *} \\
(0.084)\end{array}$ & $\begin{array}{c}0.223^{* *} \\
(0.100)\end{array}$ & $\begin{array}{l}0.278^{* * *} \\
(0.070)\end{array}$ \\
\hline Per capita GDP (square) & $\begin{array}{l}-0.015^{* * *} \\
(0.005)\end{array}$ & $\begin{array}{l}-0.016^{* *} \\
(0.007)\end{array}$ & $\begin{array}{l}-0.014^{* * *} \\
(0.003)\end{array}$ \\
\hline \multicolumn{4}{|c|}{ Community size (ref.: less than 100,000 residents) } \\
\hline $100-200,000$ residents & & $\begin{array}{l}0.186^{* * *} \\
(0.067)\end{array}$ & $\begin{array}{l}0.194^{* * *} \\
(0.069)\end{array}$ \\
\hline$>200,000$ residents & & $\begin{array}{l}0.220^{* * * *} \\
(0.068)\end{array}$ & \\
\hline$>200,000$ residents (without Bucharest) & & & $\begin{array}{l}0.270^{* * *} \\
(0.079)\end{array}$ \\
\hline Bucharest & & & $\begin{array}{l}-0.411^{*} \\
(0.229)\end{array}$ \\
\hline \multicolumn{4}{|l|}{ Year dummies (ref.: 2004) } \\
\hline 2005 & $\begin{array}{l}-0.302^{* * *} \\
(0.020)\end{array}$ & $\begin{array}{l}-0.299^{* * *} \\
(0.024)\end{array}$ & $\begin{array}{l}-0.321^{* * *} \\
(0.082)\end{array}$ \\
\hline 2006 & $\begin{array}{l}-0.296^{* * *} \\
(0.056)\end{array}$ & $\begin{array}{l}-0.292^{* * *} \\
(0.055)\end{array}$ & $\begin{array}{l}-0.330^{* * *} \\
(0.060)\end{array}$ \\
\hline 2007 & $\begin{array}{l}-0.124^{* *} \\
(0.050)\end{array}$ & $\begin{array}{l}-0.113^{* *} \\
(0.057)\end{array}$ & $\begin{array}{l}-0.174^{* * *} \\
(0.055)\end{array}$ \\
\hline 2008 & $\begin{array}{l}-0.191 \\
(0.131)\end{array}$ & $\begin{array}{l}-0.173^{* * *} \\
(0.035)\end{array}$ & $\begin{array}{l}-0.260^{* *} \\
(0.115)\end{array}$ \\
\hline 2009 & $\begin{array}{l}-0.126 \\
(0.080)\end{array}$ & $\begin{array}{l}-0.103 \\
(0.089)\end{array}$ & $\begin{array}{l}-0.222^{* * *} \\
(0.051)\end{array}$ \\
\hline 2010 & $\begin{array}{l}-0.761^{* * *} \\
(0.072)\end{array}$ & $\begin{array}{l}-0.745^{* * *} \\
(0.085)\end{array}$ & $\begin{array}{l}-0.838^{* * *} \\
(0.062)\end{array}$ \\
\hline Constant & $\begin{array}{l}-0.302^{* * *} \\
(0.020)\end{array}$ & $\begin{array}{l}-0.299^{* * * *} \\
(0.024)\end{array}$ & $\begin{array}{l}-0.321 \text { *** } \\
(0.082)\end{array}$ \\
\hline Individual characteristics & Yes & Yes & Yes \\
\hline Regional dummies & Yes & Yes & Yes \\
\hline Observations & 16,223 & 16,223 & 16,223 \\
\hline
\end{tabular}

Standard errors clustered at the year and NUTS2 level in parentheses. ${ }^{* * *} \mathrm{p}<0.01,{ }^{* *}$ $\mathrm{p}<0.05,{ }^{*} \mathrm{p}<0.1$

Source: authors' own elaborations

beginning of the economic crisis, in 2010, when the reduction in GDP is also associated to a decrease in life satisfaction. These findings seem to support the Easterlin intuition only under some circumstances. In more detail, during periods of economic recession life satisfaction follows the same path of per capita GDP. In phases of economic expansion, on the other hand, the same evidence does not hold.

\section{Conclusions}

This paper has explored the evolution of life satisfaction over time and across space in Romania in the period 1996-2010. In so doing, the paper has extended previous analyses on the subject (Lenzi, Perucca 2016b) by underlining that the relationship between transition, life satisfaction and urbanization is far from straightforward and the original Easterlin intuition cannot be translated uniformly in a spatial setting. Moreover, our findings suggest that the temporal dimension plays a relevant role as well. Our results, in fact, seem to support the Easterlin intuition and the hypothesized trade-off between economic growth and individual well-being only under some circumstances. In particular, the analysis highlights that the economic growth benefits deriving from transition have been reaped especially by the largest, capital city at detriment, however, of people's 
1996-2004

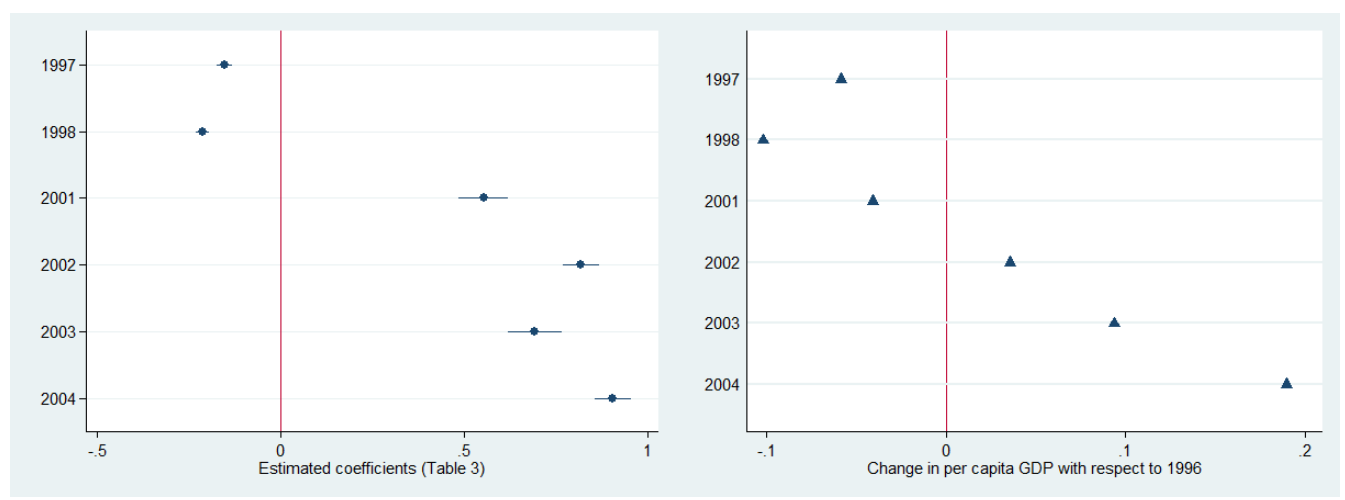

2004-2010

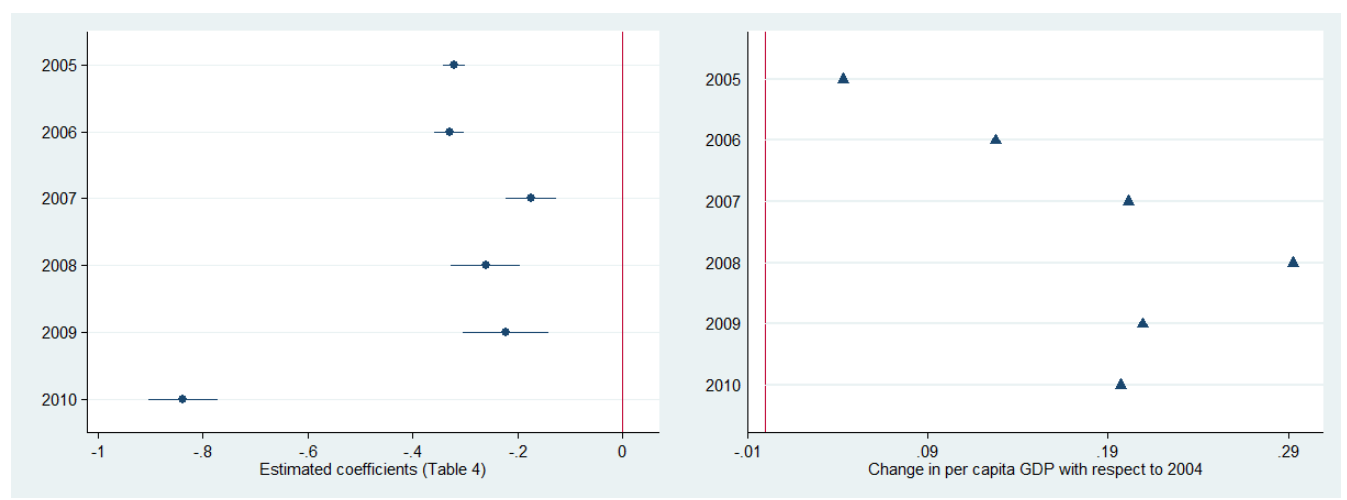

Figure 3: Estimated coefficients and change in per capita GDP over time

Source: authors' own elaborations

well-being. In this case, GDP growth was accompanied by increasing disparities in terms of economic standards with respect to residents of other types of settings, thus translating in the end, into worse well-being prospects. Yet, this conclusion does not apply to medium-large cities. In these cases, instead, economic growth was not characterized by disparities as large as in the case of Bucharest and in the end teamed with increasing life satisfaction. Moreover, in periods of economic recession life satisfaction follows the same path of per capita GDP whilst the same evidence does not hold in periods of economic expansion.

Importantly, our findings seems to suggest that the hypothesized trade-off between economic growth and well-being is not spatially neutral and that under some circumstance there are opportunities to make the two objectives matching. The achievement of such a virtuous combination between growth and well-being (i.e., competitiveness and cohesion, as it could be rephrased in the EU policy jargon) primarily depends on limited (or at least not diverging) wealth and growth gaps. If this is the case, cities and the related agglomeration benefits could actually translate in enhanced individual life satisfaction.

Our analysis certainly presents limitations in terms of geographical extension (and consequent generalization of results) as the analysis covers only one country; nonetheless, these limitations can turn into important opportunities to enlarge the research on this topic. One interesting and promising avenue of investigation concerns a deeper understanding of the interaction between spatial and temporal reach of direct and indirect urbanization effects on the individual well-being of residents of cities of different size across the EU space. We hope to extend our future research in this direction. 


\section{References}

Andrén D, Martinsson P (2006) What contributes to life satisfaction in transitional Romania? Review of Development Economics 10: 59-70. CrossRef.

Appleton S, Song L (2008) Life satisfaction in urban china: Components and determinants. World Development 36: 2325-2340. CrossRef.

Berry BJL, Okulicz-Kozaryn A (2009) Dissatisfaction with life cities. Cities 29: 117-127. CrossRef.

Berry BJL, Okulicz-Kozaryn A (2011) An urban-rural happiness gradient. Urban Geography 32: 871-883

Blanchflower DG, Freeman RB (1997) The attitudinal legacy of communist labor relations. Industrial \& Labor Relations Review 50: 438-459

Blanchflower DG, Oswald AJ (2011) International happiness: A new view on the measure of performance. The Academy of Management Perspectives 25: 6-22. CrossRef.

Di Tella R, MacCulloch R (2008) Gross national happiness as an answer to the Easterlin paradox? Journal of Development Economics 86: 22-42. CrossRef.

Dijkstra L, Garcilazo E, McCann P (2013) The economics performance of european city and city-regions: myths and realities. European Planning Studies 21: 334-354. CrossRef.

Dolan P, Peasgood T, White M (2008) Do we really know what makes us happy? a review of the economic literature on the factors associated to subjective well-being. Journal of economic Psychology 29: 94-122. CrossRef.

Easterlin RA (1995) Will raising the incomes of all increase the happiness of all? Journal of Economic Behavior and Organization 27: 35-47. CrossRef.

Easterlin RA (2009) Lost in transition: Life satisfaction on the road to capitalism. Journal of Economic Behavior \& Organization 71: 130-145

Easterlin RA, Angelescu L, Zweig JS (2011) The impact of modern economic growth on urban-rural differences in subjective well-being. World Development 39: 2187-2198. CrossRef.

Easterlin RA, McVey LA, Switek M, Sawangfa O, Zweig JS (2010) The happiness-income paradox revisited. Proceedings of the National Academy of Sciences 107: 22463-22468. CrossRef.

Easterlin RA, Plagnol AC (2008) Life satisfaction and economic conditions in East and West Germany pre-and post-unification. Journal of Economic Behavior 6 Organization 68: 433-444

Ferrara AR, Nisticò R (2015) Regional well-being indicators and dispersion from a multidimensional perspective: evidence from Italy. The Annals of Regional Science 55: 373-420. CrossRef.

Frey WH, Stutzer A (2000) Happiness, economy and institutions. The Economic Journal 110: 918-938. CrossRef.

Glaeser EL (2011) Triumph of the city: how our greatest invention makes us richer, smarter, greener, healthier, and happier. The Penguin Press, New York:

Glaeser EL, Gottlieb JD, Ziv O (2016) Unhappy cities. Journal of Labor Economics 43: S129-S182. CrossRef.

Glaeser EL, Kahn ME (2004) Sprawl and urban growth. In: JV H, JF T (eds), Handbook of Regional and Urban Economics, Volume 4. Elsevier, Amsterdam, 2481-2527. CrossRef. 
Glaeser EL, Kahn ME (2008) The greenness of cities: Carbon dioxide emissions and urban development. Journal of Urban Economics 67: 404-418. CrossRef.

Glaeser EL, Kahn ME (2010) The greenness of cities: carbon dioxide emissions and urban development. Journal of urban economics 67: 404-418. CrossRef.

Glaeser EL, Sacerdote B (1999) Why is there more crime in cities? Journal of Political Economy 107: S225-S258. CrossRef.

Guriev S, Zhuravskaya E (2009) (un)happiness in transition. Journal of Economic Perspectives 23: 143-68. CrossRef.

Hayo B (2007) Happiness in transition: An empirical study on Eastern Europe. Economic Systems 31: 204-221. CrossRef.

Kallioras D, Petrakos G (2010) Industrial growth, economic integration and structural change: evidence from the EU new member-states regions. The Annals of Regional Science 45: 667-680

Knight J, Gunatilaka R (2010) The rural-urban divide in China: Income but not happiness? Journal of Development Studies 46: 506-534. CrossRef.

Lelkes O (2006) Knowing what is good for you: Empirical analysis of personal preferences and the "objective good". The Journal of Socio-Economics 35: 285-307

Lenzi C, Perucca G (2016a) Are urbanized areas source of life satisfaction? Evidence from EU regions. Papers in Regional Science. CrossRef.

Lenzi C, Perucca G (2016b) Life satisfaction across cities: evidence from romania. Journal of Development Studies. CrossRef.

Mariana CC (2012) Sources of variation in quality of life in Romania. Procedia-Social and Behavioral Sciences 58: 645-654. CrossRef.

Morrison PS (2011) Local expressions of subjective well-being: The New Zealand experience. Regional Studies 45: 1039-1058. CrossRef.

Morrison PS (2014) The measurement of regional growth and well-being. In: Fischer MM, Nijkamp P (eds), Handbook of regional growth. Springer Verlag, Berlin, Heidelberg, 277-289. CrossRef.

Okulicz-Kozaryn A (2012) Income and well-being across European provinces. Social Indicators Research 106: 371-392. CrossRef.

Oswald AJ, Wu S (2010) Objective confirmation of subjective measures of human wellbeing: Evidence from U.S.A. Science 327: 576-579. CrossRef.

Partridge, M D andRickman DS, Kamar A, Olfert MR (2009) Do new economic geography agglomeration shadows underlie current population dynamics across the urban hierarchy? Papers in Regional Science 88: 445-466. CrossRef.

Piper AT (2015) Europe's capital cities and the happiness penalty: an investigation using the European Social Survey. Social Indicators Research 123: 103-126. CrossRef.

Puga D (2010) The magnitude and causes of agglomeration economies. Journal of Regional Science 50: 203-219. CrossRef.

Rehdanz K, Maddison D (2005) Climate and happiness. Ecological Economics 52: 111-125. CrossRef.

Requena F (2015) Rural-urban living and level of economic development as factors in subjective well-being. Social Indicators Research. CrossRef. 
Rodríguez-Pose A, Maslauskaite K (2012) Can policy make us happier? individual characteristics, socio-economic factors and life satisfaction in Central and Eastern Europe. Cambridge Journal of Regions, Economy and Society 5: 77-96. CrossRef.

Rosenthal SS, Strange WC (2004) Evidence on the nature and sources of agglomeration economies. In: Henderson J, Thisse JF (eds), Handbook of Urban and Regional Economics, Volume 4. Elsevier, Amsterdam, 2119-2172. CrossRef.

Sanfey P, Teksoz U (2007) Does transition make you happy? Economics of Transition 15: 707-731. CrossRef.

Shucksmith M, Cameron S, Merridew T, Pichler F (2009) Urban-rural differences in quality of life across the European Union. Regional Studies 43: 1275-1289. CrossRef.

Sørensen JF (2014) Rural-urban differences in life satisfaction: Evidence from the European Union. Regional Studies 48: 1451-1466. CrossRef.

Tomaney J (2015) Region and place iii: well-being. Progress in human geography. CrossRef. 


\section{A Appendix}

\section{A.1 Appendix A. Ordered logistic results}

Table A.1 reports the results from an ordered logistic regression on the four level of life satisfaction, employing the same specification of model (3), Table 2. The interpretation of the coefficients and their significance are consistent with those discussed in the main paper (see Table 2 and Table A.2). Nevertheless, the Brant test rejected the hypothesis on the validity of the parallel regression assumption (Table A.1) for several variables making the binomial logit model more suitable for the empirical analysis of this paper. 
Table A.1: Life satisfaction, individual and regional characteristics: ordered logit results

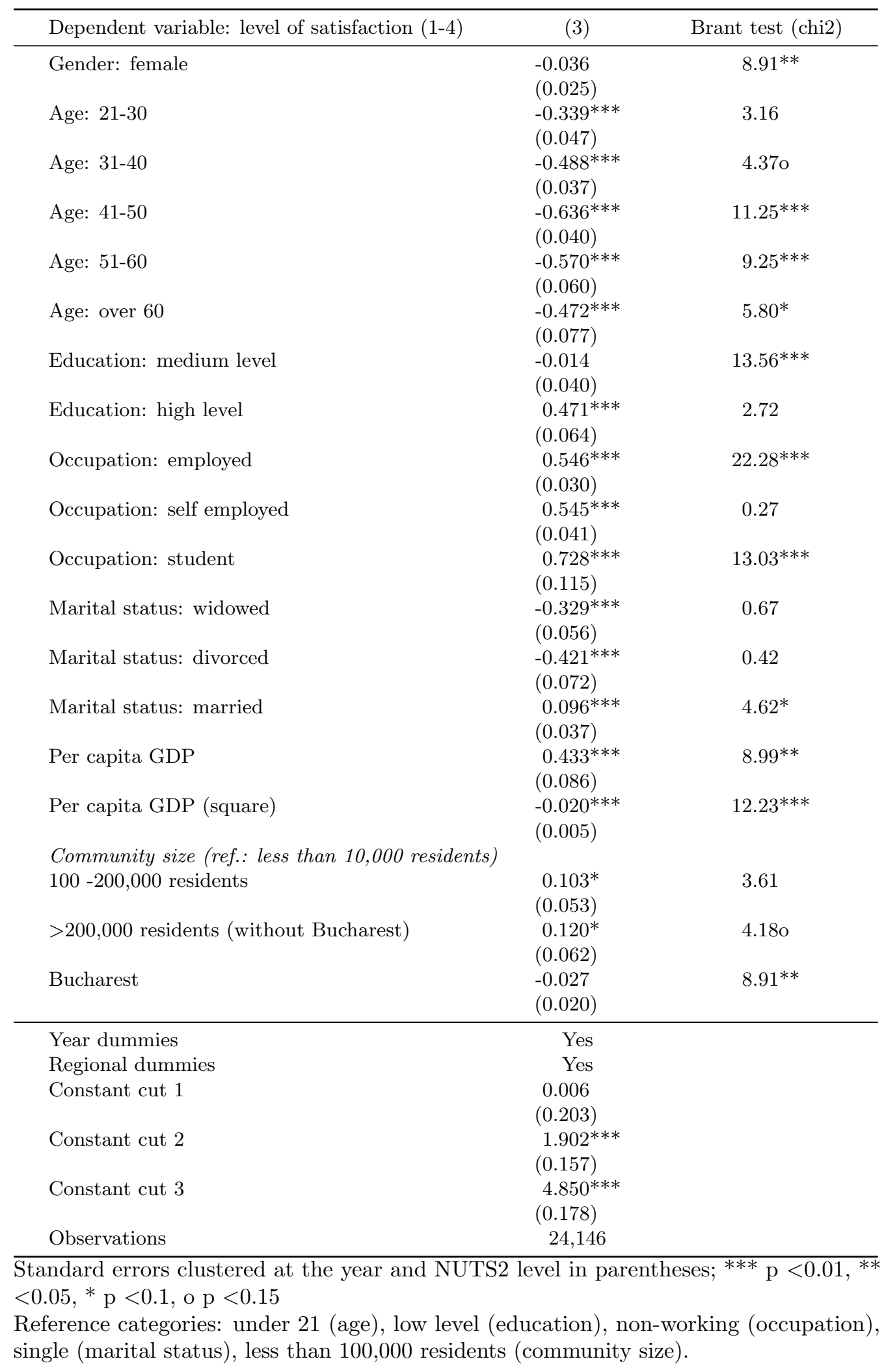




\section{A.2 Life satisfaction and individual characteristics of the respondents}

As discussed in Section 3.2, life satisfaction was regressed on a set of individual characteristics. Results are reported in Table A.2. The three models in Table A.2 differ according to the typology of regional controls included (Table 2). Among other things, our findings indicate that younger people are happier than older people, with a U-shaped effect: people aged between 51-60 are happier than those aged between 41-50, and people aged over 60 are even happier than those aged between 31-40. Highly educated people are also happier with respect to those with low educational attainment. Employed, self-employed and students are more satisfied than people that do not work. Married people are also happier than singles, whereas divorcees and widows/widowers are less satisfied than singles. Finally, females do not appear to be happier than males. These effects are consistent across all models displayed in Tables 3 to 5 . It is important to remember that the interpretation of these individual effects has to be done in relative terms with respect to the reference cases (mentioned in the note to Table A.2). As to the age effect, in particular, the coefficient of the dummy variables indicate that the effect of age is U-shaped, with a minimum around 40-50 years. Dolan et al. (2008) as well as Blanchflower, Oswald (2011) report that generally the minimum is between 30 and 50 , depending on the study. Moreover, Dolan et al. (2008) indicate that, even if women tend to be happier than men are, the statistical significance of its effect frequently disappears when other controls are inserted. 
Table A.2: Life satisfaction and individual characteristics of the respondents

\begin{tabular}{|c|c|c|c|}
\hline Dependent variable: satisfied/very satisfied $=1$ & $(1)$ & $(2)$ & $(3)$ \\
\hline Gender: female & $\begin{array}{l}-0.012 \\
(0.028)\end{array}$ & $\begin{array}{l}-0.014 \\
(0.028)\end{array}$ & $\begin{array}{l}-0.013 \\
(0.028)\end{array}$ \\
\hline Age: 21-30 & $\begin{array}{l}-0.304^{* * *} \\
(0.036)\end{array}$ & $\begin{array}{l}-0.310^{* * *} \\
(0.042)\end{array}$ & $\begin{array}{l}-0.313^{* * *} \\
(0.040)\end{array}$ \\
\hline Age: $31-40$ & $\begin{array}{c}-0.422 \\
(.)\end{array}$ & $\begin{array}{c}-0.426 \\
(.)\end{array}$ & $\begin{array}{l}-0.426 \\
(.)\end{array}$ \\
\hline Age: $41-50$ & $\begin{array}{l}-0.574^{* * *} \\
(0.077)\end{array}$ & $\begin{array}{l}-0.578^{* * *} \\
(0.078)\end{array}$ & $\begin{array}{l}-0.583^{* * *} \\
(0.078)\end{array}$ \\
\hline Age: 51-60 & $\begin{array}{l}-0.558^{* * *} \\
(0.046)\end{array}$ & $\begin{array}{l}-0.562^{* * *} \\
(0.047)\end{array}$ & $\begin{array}{l}-0.565^{* * *} \\
(0.046)\end{array}$ \\
\hline Age: over 60 & $\begin{array}{l}-0.373^{* * *} \\
(0.095)\end{array}$ & $\begin{array}{l}-0.375^{* * *} \\
(0.095)\end{array}$ & $\begin{array}{l}-0.377^{* * *} \\
(0.094)\end{array}$ \\
\hline Education: medium level & $\begin{array}{l}-0.076 \\
(0.050)\end{array}$ & $\begin{array}{l}-0.081 \\
(0.051)\end{array}$ & $\begin{array}{l}-0.076 \\
(0.050)\end{array}$ \\
\hline Education: high level & $\begin{array}{l}0.492^{* * *} \\
(0.079)\end{array}$ & $\begin{array}{l}0.472^{* * *} \\
(0.080)\end{array}$ & $\begin{array}{l}0.477^{* * *} \\
(0.081)\end{array}$ \\
\hline Occupation: employed & $\begin{array}{l}0.536^{* * *} \\
(0.045)\end{array}$ & $\begin{array}{l}0.530^{* * *} \\
(0.044)\end{array}$ & $\begin{array}{l}0.523^{* * *} \\
(0.043)\end{array}$ \\
\hline Occupation: self employed & $\begin{array}{l}0.540^{* * *} \\
(0.064)\end{array}$ & $\begin{array}{l}0.547^{* * *} \\
(0.065)\end{array}$ & $\begin{array}{l}0.551^{* * *} \\
(0.064)\end{array}$ \\
\hline Occupation: student & $\begin{array}{l}0.726^{* * *} \\
(0.085)\end{array}$ & $\begin{array}{l}0.720^{* * *} \\
(0.092)\end{array}$ & $\begin{array}{l}0.709^{* * *} \\
(0.087)\end{array}$ \\
\hline Marital status: widowed & $\begin{array}{l}-0.306^{* * *} \\
(0.096)\end{array}$ & $\begin{array}{l}-0.304^{* * *} \\
(0.097)\end{array}$ & $\begin{array}{l}-0.303^{* * *} \\
(0.098)\end{array}$ \\
\hline Marital status: divorced & $\begin{array}{l}-0.423^{* * *} \\
(0.064)\end{array}$ & $\begin{array}{l}-0.426^{* * *} \\
(0.066)\end{array}$ & $\begin{array}{l}-0.427^{* * *} \\
(0.066)\end{array}$ \\
\hline Marital status: married & $\begin{array}{l}0.101^{* * *} \\
(0.021)\end{array}$ & $\begin{array}{l}0.104^{* * *} \\
(0.020)\end{array}$ & $\begin{array}{l}0.106^{* * *} \\
(0.023)\end{array}$ \\
\hline Constant & $\begin{array}{l}-3.184^{* * *} \\
(0.338)\end{array}$ & $\begin{array}{l}-3.296^{* * *} \\
(0.389)\end{array}$ & $\begin{array}{l}-3.049^{* * *} \\
(0.320)\end{array}$ \\
\hline GDP per capita & Yes & Yes & Yes \\
\hline Community size & No & Yes & Yes \\
\hline Year dummies & Yes & Yes & Yes \\
\hline Regional dummies & Yes & Yes & Yes \\
\hline Observations & 24,146 & 24,146 & 24,146 \\
\hline
\end{tabular}


A.3 Life satisfaction and the role of regional income per capita

Table A.3: Life satisfaction and the role of regional income per capita

\begin{tabular}{|c|c|c|c|}
\hline Dependent variable: satisfied/very satisfied $=1$ & (1) & $(2)$ & $(3)$ \\
\hline Net disposable income & $\begin{array}{l}0.038^{* *} \\
(0.018)\end{array}$ & $\begin{array}{c}0.034 \\
(0.021)\end{array}$ & $\begin{array}{l}0.049^{* * *} \\
(0.013)\end{array}$ \\
\hline Net disposable income (square) & $\begin{array}{l}-0.000^{* *} \\
(0.000)\end{array}$ & $\begin{array}{l}-0.000^{*} \\
(0.000)\end{array}$ & $\begin{array}{l}-0.000^{* * *} \\
(0.000)\end{array}$ \\
\hline $\begin{array}{l}\text { Community size (ref: less than } 100,000 \text { resident } \\
100-200,000 \text { residents }\end{array}$ & & $\begin{array}{l}0.185^{* * *} \\
(0.066)\end{array}$ & $\begin{array}{l}0.194^{* * *} \\
(0.066)\end{array}$ \\
\hline$>200,000$ residents & & $\begin{array}{l}0.185^{* * *} \\
(0.060)\end{array}$ & \\
\hline$>200,000$ residents (without Bucharest) & & & $\begin{array}{l}0.265^{* * *} \\
(0.078)\end{array}$ \\
\hline Bucharest & & & $\begin{array}{l}-0.394^{*} \\
(0.205)\end{array}$ \\
\hline Constant & $\begin{array}{l}-0.863^{* * *} \\
(0.068)\end{array}$ & $\begin{array}{l}-1.505^{* * *} \\
(0.384)\end{array}$ & $\begin{array}{l}-1.432^{* * *} \\
(0.445)\end{array}$ \\
\hline Individual characteristics & Yes & Yes & Yes \\
\hline Regional dummies & Yes & Yes & Yes \\
\hline Year dummies & Yes & Yes & Yes \\
\hline Observations & 16,223 & 16,223 & 16,223 \\
\hline
\end{tabular}

